\title{
The Avonlea Projectile Point
}

\author{
by Thomas F. Kehoe and Bruce A. McCorquodale,
} Saskatchewan Museum of Natural History

It is only recently that detailed analyses have been made of the small, triangular, side-notched projectile points characteristic of the Late Prehistoric Period (approximately A.D. 400-1750) in the Northern Plains. When the sequence of these small points in stratified sites is examined, however, it becomes apparent that in Saskatchewan, especially, the beginning of the sequence is marked by the presence of a thin, delicate type of point that has come to be known as an "Avonlea point."

The point type is named after the type site of Avonlea, in south-central Saskatchewan, where the points are found unmixed with other types. This site was visited in October, 1956, by McCorquodale and A. E. Swanston, staff members of the Saskatchewan Museum of Natural History, under the guidance of the late Alan J. Hudson of Mortlach. The party tested on a knoll in a small valley: this knoll appeared to be a part of a bison drive site. A blown field near the knoll yielded a surface collection of points of several periods, early and late, as well as a large pottery vessel, but the lack of stratification in the field made it impossible to determine either the local sequence of points or the period to which the pottery belonged.

The distribution of Avonlea points covers 450 miles, east-west. These points occur, on the east, near Melfort, Indian Head, and in the Long Creek site excavated by Wettlaufer and Mayer-Oakes in 1957. On the west, Avonlea points have been found near Fort Macleod, Alberta, and near Shelby, Montana. The center of the point's distribution is in southwestern Saskatchewan, and sites in this locality have produced what appear to be the earliest Avonlea points, plus later, degenerate forms of this point. The Saskatchewan Museum's work at the Gull Lake Bison Drive site, in the southwest of the province, promises to contribute a definite sequence of small side-notched triangular points for this region. Tests by Wettlaufer at the Gull Lake site in 1953 resulted in a series of Avonlea points, and full-scale excavations begun by Kehoe in 1960 have been adding to our knowledge of this period and the succeeding one.

The region in which Avonlea points occur has been glaciated, so that the terrain varies from gently undulating ground moraine to end moraine with hills and ponds. The drainage system of this region is poorly established, with meltwater channels carrying off only a very small part of the precipitation. Most of the run-off remains in the numerous ponds (glacial kettles), which lack outlets.

The Missouri Coteau, a prominent but discontinuous line of hills, runs through the region, with short-grass prairie steppe lying above and to the west of the Coteau. Local deposits of Tertiary gravels have resulted in smaller, higher plateaus resting on this steppe, the gravels protecting the softer Tertiary and Cretaceous sands and clays beneath from erosion. Meltwater streams have carved deep, steep-sided coulees on the edges of the steeper escarpments.

Particularly in the central portion of Avonlea points' distribution, summers are hot and dry, winters are cold, dry, but relieved by mild spells ("chinooks"), and conditions are generally arid. The aridity prevents establishment of trees, except in the highest or best-watered locations, although marsh grasses grow profusely in the many ponds. The climate was excellent for bison, and the topography ideal for the communal methods of bison hunting through driving and corralling.

An examination made by the authors of 176 Avonlea points from sites throughout the Avonlea range defined the point type in the following terms: The Avonlea is a very delicate point, made on a thin flake. Workmanship is excellent, with flake scars broad and shallow and both faces usually entirely dressed. Side notches on the triangular point are small, shallow, but fairly wide, and placed extremely low on the blade. These notches are $\mathrm{V}$ or U-shaped, never rectangular; they are equidistant from the base and symmetrically opposed. Ninety-nine per cent of the notches begin three millimetres or less from the base of the point. The 
Vol. XIX No, 3

\section{The Avonlea Projectile Point}
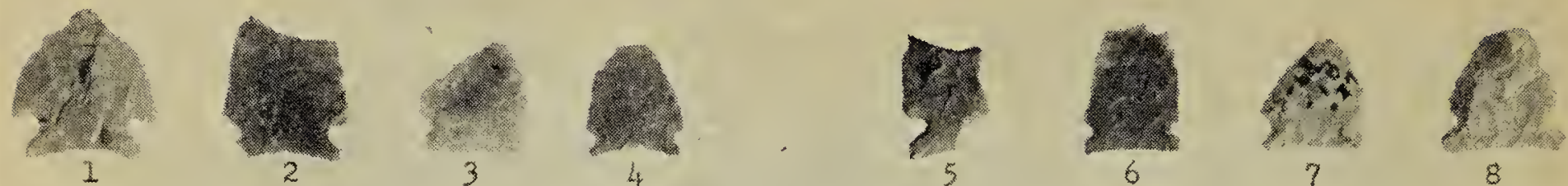

7

8
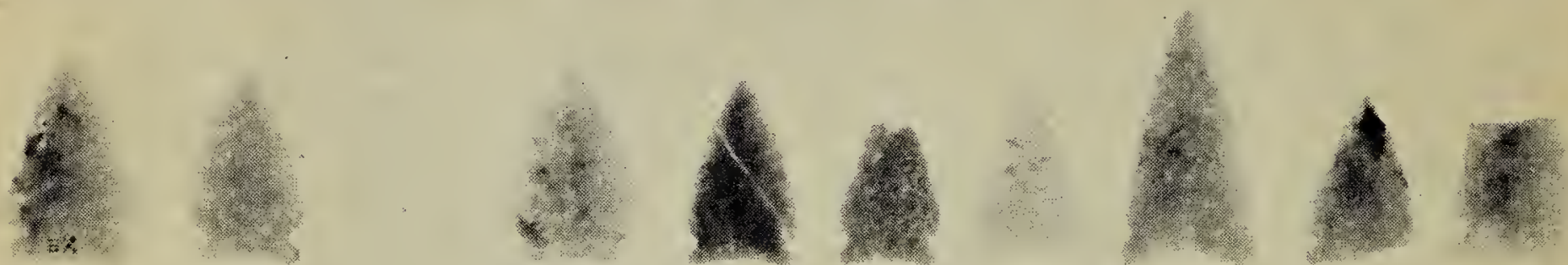

11

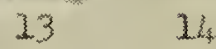

15

17

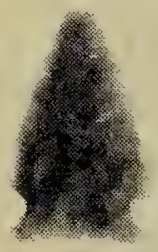

18
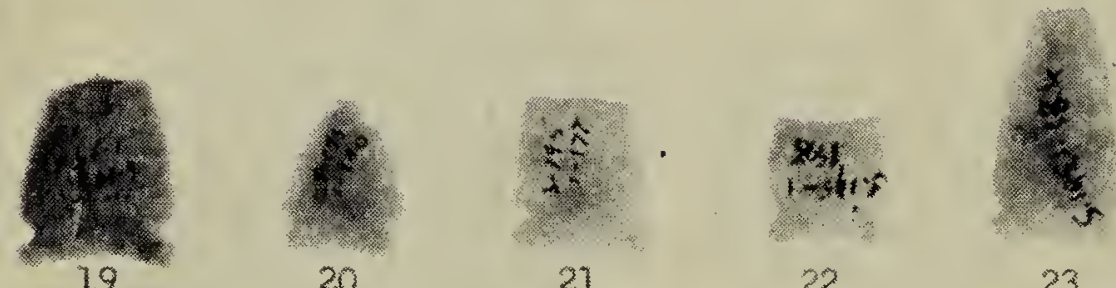

21

22

23
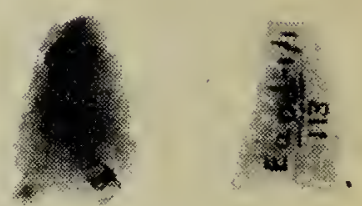

234

25

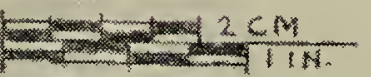

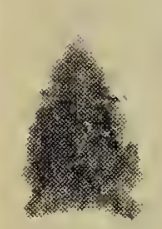

26

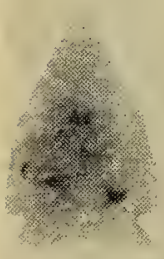

35

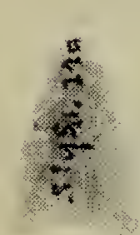

27

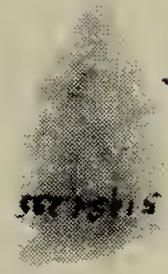

28

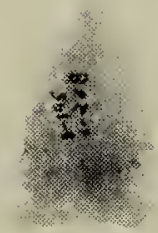

29

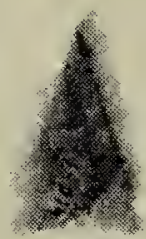

30

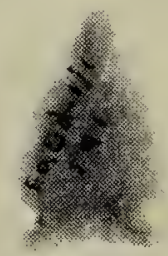

31

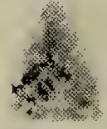

32

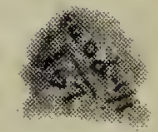

33

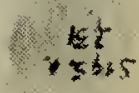

34

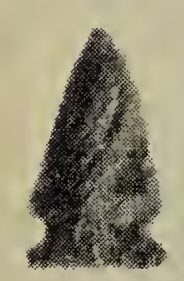

36
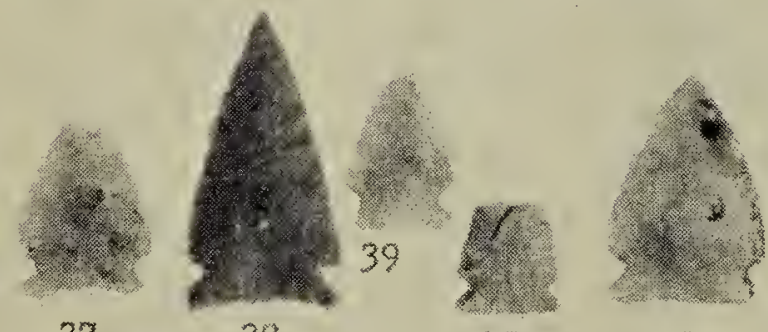

41
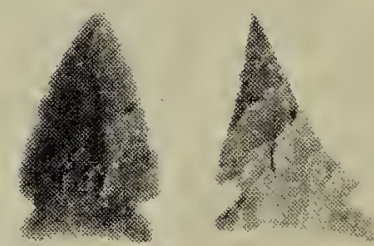

43

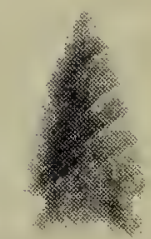

44

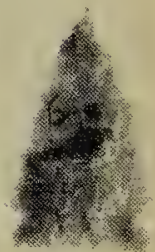

45
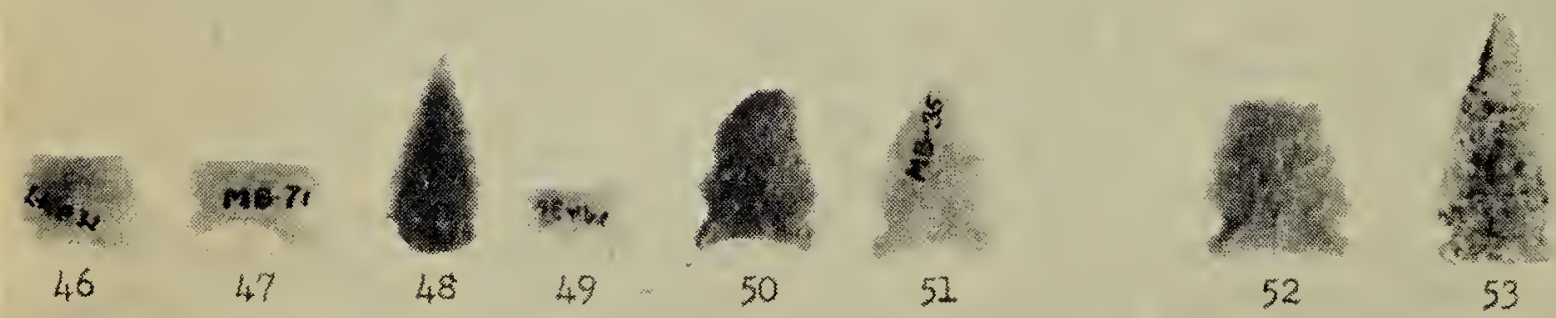

52

53
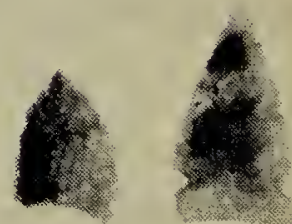

54

55
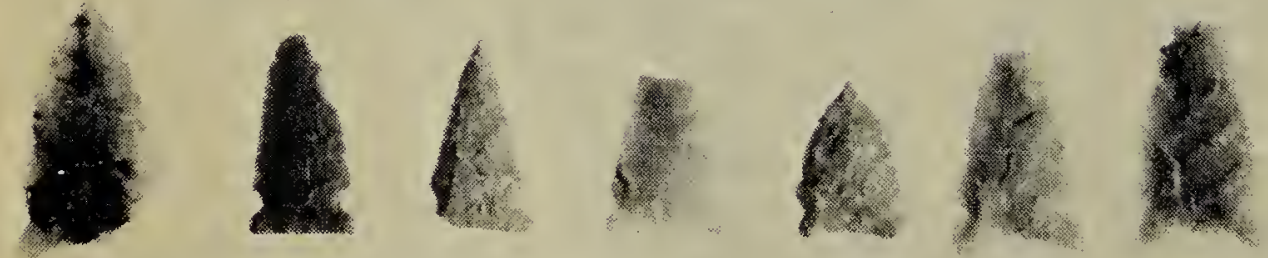

62
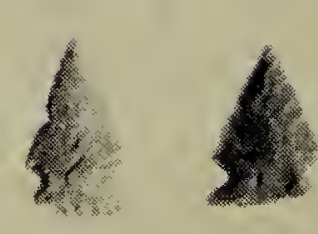

64

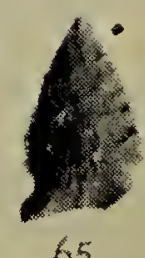

61

63

65

Avonlea points: 1-4, Long Creek site; 5-8, Cherry Lake site; 9-10, Kyle site; 11-17, surface finds at Gull Lake sitie; 18-25, 45" to 53" at Gull Lake; 26-34, 53" to 64" at Gull Lake; 34-45, Avonlea site; 46-51, Mclean site; 52-55, Bakken-Wright site layer; 56-65, Rinehardt site. 
edges of the blade are regular and often finely serrated. Bases may be wider than, equal to; or less than the proximal end of the blade, but most of the bases are concave; some are straight, but none are convex. The corners of the base are rounded, and small projecting ears are common. Seventy-eight per cent of all bases are very lightly ground.

Length of specimens range from $12.0 \mathrm{~mm}$. to $38.0 \mathrm{~mm}$., averaging 20.8 $\mathrm{mm}$. Width ranges from 9.0 to 18.5 $\mathrm{mm}$., averaging $13.4 \mathrm{~mm}$. Thickness ranges from 2.0 to $4.0 \mathrm{~mm}$., averaging $2.47 \mathrm{~mm}$. The average length-width ratio is $1.5: 1$; average width-thickness ratio 5.6:1. The average weight is 0.68 gms., with the range between 0.2 to $1.8 \mathrm{gms}$.

Flint, chert, and quartzite are the principal minerals used for Avonlea points. The dark brown, "Knife River flint" (brown chalcedony) preferred by other Saskatchewan aboriginal peoples does not seem to have been available to the Avonlea point makers, although the chalcedony quarries in North Dakota were not so greatly distant.

A sample of charcoal collected by McCorquodale on October 1, 1956, from the Avonlea site, test pit 1, was radio-carbon dated by the University of Saskatchewan (Sample S-45) and gave an age of $1500 \pm 100$ years; that is the Avonlea points date from approximately 460 A.D. In stratigraphic excavations at bison kills, Avonlea appears deep beneath the surface, under the cruder types of small, triangular, side-notched points. We believe that the Avonlea complex is probably pre-ceramic, because we have not seen any indubitable associations of Avonlea points with pottery, although there are examples of Avonleas with sherds in disturbed or in poorly-stratified deposits.

The relationships of Avonlea points to preceding types is at present unclear. The Avonlea most closely resemble in outline the larger, but much cruder and much earlier ( $5200 \pm 130$ years old by radiocarbon) projectile points found at the Oxbow Dam site (Nero and McCorquodale 1958). The fine workmanship on Avonlea points is paralleled in the quality of Pelican Lake points found at the Long Creek site (Wettlaufer, 1960), but the Pelican Lakes not only are 800 years ear- lier than the Avonlea, but also bear little other detailed resemblance. Very few of the points that succeed Avonlea in time, either, show form or workmanship similar to that of Avonlea, except in broad terms.

If we may be permitted to indulge in speculation, we would like to note that the correlation of Avonlea point distribution with the distribution of glaciated "knob-and-kettle" topography appears to us to be significant. This topography would favor a dependence upon communal bison drives in the aboriginal population. In bison drives, the herd was stampeded into a corral, natural or artificial (often, but not necessarily, over a steep drop). Once in the corral, the wildly milling animals were despatched at close range by arrows. Now, under these conditions the best type of arrowpoint would have been a small, thin, sharp-edged point with deep penetration; there was no need for large, heavy points giving accuracy and good impact over a distance. The Avonlea point would thus have been more suitable for a people who usually slaughtered their meat after driving it into a corral. The Avonlea point would have also been economical of materials, being thin, and we have noted above that these points seem to have been manufactured from the somewhat limited local sources of stone, rather than from imported minerals. Thus, the Avonlea point type may have been a response to the stimulus of a new method of hunting and/or restriction on the importation of projectile point raw material.

\section{LITERATURE CITED}

Nero, Robert W. and Bruce A. McCorquodale 1958. Report of an Excavation at the Oxbow Dam Site. The Blue Jay, 16:82-90.

We, ¿laufer. Bovd

1960. The Long Creek Site. Saskatchewan Museum of Natural History, Anthropological Series No. 2. Department of Natural Resources, Regina.

\section{CORRECTION}

The length of the Grand Coulee stone "hoe" described by $\mathrm{Mr}$. G. Watson, Pense, in the Blue Jay, pp. 97-98, June, 1961, is actually only $228 \mathrm{~mm}$. and not $280 \mathrm{~mm}$. The picture shows it nearly as large as the Squaw Rapids (230 mm.) "hoe." The artifact was found on the NE $1 / 4$ 20-16-21-W2. 